\title{
Toll-Like Receptor-3 Activation Increases the Vulnerability of the Neonatal Brain to Hypoxia-Ischemia
}

\author{
Linnea Stridh, ${ }^{1}$ Amin Mottahedin, ${ }^{1}$ Maria E. Johansson, ${ }^{1}$ Raul Chavez Valdez, ${ }^{2}$ Frances Northington, ${ }^{2}$ Xiaoyang Wang, ${ }^{1}$ \\ and Carina Mallard ${ }^{1}$ \\ ${ }^{1}$ Department of Neuroscience and Physiology, Sahlgrenska Academy, University of Gothenburg, S-40530 Gothenburg, Sweden, and ${ }^{2}$ Neonatal Research \\ Laboratory, Department of Pediatrics, Johns Hopkins University School of Medicine, Baltimore, Maryland 21287-3200
}

\begin{abstract}
Susceptibility and progression of brain injury in the newborn is closely associated with an exacerbated innate immune response, but the underlying mechanisms are often unclear. Toll-like receptors (TLRs) are important innate immune sensors that may influence the vulnerability of the developing brain. In the current study, we provide novel data to show that activation of the viral innate immune receptor TLR-3 sensitizes the neonatal brain to subsequent hypoxic-ischemic (HI) damage. Poly inosinic:poly cytidylic acid (Poly I:C), a synthetic ligand for TLR-3, was administered to neonatal mice $14 \mathrm{~h}$ before cerebral HI. Activation of TLR-3 before HI increased infarct volume from $3.0 \pm 0.5$ to $15.4 \pm 2.1 \mathrm{~mm}^{3}$ and augmented loss of myelin basic protein from $13.4 \pm 6.0$ to $70.6 \pm 5.3 \%$. The sensitizing effect of Poly I:C was specific for the TLR-3 pathway because mice deficient in the TLR-3 adaptor protein Toll/IL-1R domain-containing adaptor molecule-1 (TRIF) did not develop larger brain damage. The increased vulnerability was associated with a TRIF-dependent heightened inflammatory response, including proinflammatory cytokines, chemokines, and the apoptosis-associated mediator Fas, whereas there was a decrease in reparative M2-like $\mathrm{CD} 11 \mathrm{~b}^{+}$microglia and phosphorylation of Akt. Because TLR-3 is activated via double-stranded RNA during most viral infections, the present study provides evidence that viral infections during pregnancy or in the neonate could have great impact on subsequent HI brain injury.
\end{abstract}

\section{Introduction}

Inflammation is an important contributing factor to CNS injury in neonates (Dammann and Leviton, 1997; Volpe, 2008). Tolllike receptors (TLRs) are instrumental in innate immune responses by recognizing pathogen-associated molecular patterns. TLRs also play a role in non-infectious situations, including cerebral ischemia. TLR-3 recognizes double-stranded RNA (dsRNA) released during viral infections, triggering the production of type 1 interferon and inflammatory cytokines/chemokines via the Toll/IL-1R domain-containing adaptor molecule-1 (TRIF). Although adult mice that lack TLR-3 or TRIF are not protected from cerebral ischemia (Hua et al., 2009; Hyakkoku et al., 2010; Famakin et al., 2011), TLR-3 activation exacerbates chronic neurodegeneration (Field et al., 2010) and triggers nigrostriatal dopaminergic degeneration (Deleidi et al., 2010). How-

Received Feb. 13, 2013; revised May 28, 2013; accepted June 13, 2013.

Author contributions: L.S., R.C.V., F.N., X.W., and C.M. designed research; L.S., A.M., and M.E.J. performed research; L.S., A.M., M.E.J., X.W., and C.M. analyzed data; L.S., R.C.V., F.N., X.W., and C.M. wrote the paper.

This research was supported by Swedish Research Council Grants VR2009-2630 and 2012-2992, Sahlgrenska University Hospital Government Grant to a Researcher in Public Health Service ALFGBG-142881, European Union Grant FP7 (Neurobid, HEALTHF2-2009-241778), Leducq Foundation Grant DSRR_P34404, the Åhlén Foundation, the Wilhelm and Martina Lundgren Foundation, the Olle Engkvist Foundation, and National Institutes of Health Grant R01HD070996. X.W. is supported by Swedish Research Council Grant VR K2009-54X-21119-01-4 and Swedish Governmental Agency for Innovation Systems Grant 2011-03458.

The authors declare no competing financial interests.

Correspondence should be addressed to Carina Mallard, Institute of Neuroscience and Physiology, Department of Physiology, Sahlgrenska Academy, University of Gothenburg, S-40530 Gothenburg, Sweden. E-mail: carina.mallard@neuro.gu.se.

DOI:10.1523/JNEUROSCI.0673-13.2013

Copyright $\odot 2013$ the authors $\quad 0270-6474 / 13 / 3312041-11 \$ 15.00 / 0$ ever, contradictory reports suggest that stimulation of the TRIF pathway may be neuroprotective by reprogramming the cerebral response to stroke (Marsh et al., 2009).

In the developing brain, TLR-3 activation impairs neural progenitor cell proliferation (Lathia et al., 2008), and maternal immune activation with poly inosinic:poly cytidylic acid (Poly I:C), a synthetic TLR-3 agonist, alters fetal brain development in an IL-6-dependent manner (Smith et al., 2007). Furthermore, maternal exposure to Poly I:C results in long-lasting effects in the offspring, including deficiencies in memory, learning tasks, and attention (Ratnayake et al., 2012; Vuillermot et al., 2012). In neonatal animals, exposure to Poly I:C increases seizure susceptibility later during adulthood (Galic et al., 2009), suggesting that TLR-3 activation during brain development has detrimental effects that may affect vulnerability to later insults. In support of a possible sensitizing effect of TLR stimulation, previous studies have shown that lipopolysaccharide (LPS), a TLR-4 ligand, can enhance the response to hypoxia-ischemia (HI) in neonatal animals (Eklind et al., 2001; Lehnardt et al., 2003).

In the present study, we hypothesized that activation of TLR-3 increases the susceptibility of the neonatal brain to HI. We used postnatal day 8 (P8) mice, which are at a brain developmental stage at which myelination has only just started, equivalent to the near-term human infant (Craig et al., 2003). We demonstrate that activation of TLR-3 markedly increased the vulnerability of the neonatal brain to HI injury in a TRIF-dependent manner, which was associated with increased induction of proinflammatory mediators, a decrease in reparative M2-like microglia phenotype and reduced phosphorylation of Akt. Because TLR-3 is 
activated via dsRNA during most viral infections, the present study provides evidence that viral infections during pregnancy or in the neonate could have great impact on subsequent $\mathrm{HI}$ brain injury.

\section{Materials and Methods}

Animals. C57BL/6J mice lacking the gene for TRIF (C57BL/6J-Ticam1Lps2/J, TRIF KO; The Jackson Laboratory) and wild-type C57BL/6J mice (WT; Charles River) were housed and bred in a $12 \mathrm{~h} \mathrm{light/dark} \mathrm{cycle} \mathrm{at} \mathrm{Experimental}$ Biomedicine (University of Gothenburg, Gothenburg, Sweden). Mixed litters were obtained from WT and TRIF KO mice; approximately five generations were bred before the start of experiments. Pups of either sex were studied. Mice were provided with a standard laboratory chow diet (Brüel and Kjær) and drinking water ad libitum. All animal experiments were approved by the Ethical Committee of Gothenburg (Protocol 374-09) and performed according to the Guidelines for the Care and Use of Laboratory Animals.

Genotyping. The genotype of TRIF KO mice was determined by RTPCR of genomic DNA obtained from mouse tails. The tail was digested with $400 \mu \mathrm{l}$ of lysis buffer $(50 \mathrm{mmol} / \mathrm{L}$ Tris- $\mathrm{HCl}, \mathrm{pH} 8.0,100 \mathrm{mmol} / \mathrm{L}$ EDTA, $100 \mathrm{mmol} / \mathrm{L} \mathrm{NaCl}$, and $1 \%$ SDS) containing $1 \mathrm{mg} / \mathrm{ml}$ proteinase $\mathrm{K}$ (Roche). After incubation at $60^{\circ} \mathrm{C}$ overnight, $200 \mu \mathrm{l}$ of $5 \mathrm{~mol} / \mathrm{L}$ potassium acetate was added to the lysate, which was then thoroughly mixed and centrifuged at $10,000 \times g$ for $20 \mathrm{~min}$. The supernatant was transferred into a clean tube, and $800 \mu \mathrm{l}$ of $100 \%$ ethanol was added and mixed. After incubation at $-20^{\circ} \mathrm{C}$ for $30 \mathrm{~min}$, the DNA was pelleted by centrifugation at $10,000 \times \mathrm{g}$ for $25 \mathrm{~min}$ at $4^{\circ} \mathrm{C}$. The pellet was washed once with $500 \mu \mathrm{l}$ of $75 \%$ ethanol. After removing all of the liquid, the pellet was left to dry at room temperature. The pellet of DNA was dissolved with $100 \mu \mathrm{l}$ of sterile water, and DNA concentration was determined.

Genotypes were detected through melt-curve-based genotyping. Primers used for the amplification step were as follows: forward, $5^{\prime}$-CC AATCCTTTCCATCAGCCT-3'; and reverse, 5' -CACTCTGGAGTCTA AGAAG-3' (Tib Molbiol). For melt-curve analysis, the following probes were used: 5' -CACATGTGGGGCCACACAGGGG-FL; and 5'-LC640CCAGTCATCTGATGACAAGACTGAG-PH (Tib Molbiol). The amplification protocol comprised an initial $5 \mathrm{~min}$ denaturation at $95^{\circ} \mathrm{C}$, followed by 40 cycles of denaturation for $30 \mathrm{~s}$ at $95^{\circ} \mathrm{C}$ and annealing/ extension for $30 \mathrm{~s}$ at $55^{\circ} \mathrm{C}$, followed by $1 \mathrm{~min}$ at $72^{\circ} \mathrm{C}$, and thereafter, a melt-curve analysis consisted of $1 \mathrm{~min}$ denaturation at $95^{\circ} \mathrm{C}$, followed by $3 \mathrm{~min}$ at $45^{\circ} \mathrm{C}$ and an increase of temperature to $95^{\circ} \mathrm{C}$ with a rate of $0.11^{\circ} \mathrm{C} / \mathrm{s}$ on a LightCycler 480 (Roche). WT mice were identified with a melting temperature of $65-66^{\circ} \mathrm{C}$, TRIF $\mathrm{KO}$ mice were identified with a melting temperature of $59-60^{\circ} \mathrm{C}$, and heterozygotes were identified by the presence of both melting temperatures.

Poly I:C pretreatment and HI. To determine the sequence of maximum TLR-3 activation, IFN- $\beta$ gene expression was investigated (for details, see below) at different time points and after different doses of Poly I:C administration. P8 mice were intraperitoneally given 5 or $10 \mathrm{mg} / \mathrm{kg}$ Poly I:C [Poly(I:C)-LMW; InvivoGen], a specific synthetic TLR-3 ligand, or LPS free saline (S8776; Sigma-Aldrich) and killed at 6, 14, and $24 \mathrm{~h}$ after injection. IFN- $\beta$ gene expression was greatest at $14 \mathrm{~h}$ after a Poly I:C dose of $10 \mathrm{mg} / \mathrm{kg}$, which was used for additional studies (data not shown).

To investigate the effect of TLR-3 activation on neonatal HI, Poly I:C $(10 \mathrm{mg} / \mathrm{kg})$ or LPS free saline (S8776; Sigma-Aldrich) was administered intraperitoneally to P8 WT and TRIF KO mice of either sex (Fig. 1) $14 \mathrm{~h}$ before the induction of HI. At P9, mice were anesthetized with isoflurane (3.0\% for induction and $1.0-1.5 \%$ for maintenance) in a mixture of nitrous oxide and oxygen (1:1). The left common carotid artery was ligated with prolene sutures (the whole procedure was $<5 \mathrm{~min}$ ). Mice were returned to the cage, allowed to recover for $1 \mathrm{~h}$, and then placed in an incubator circulated with a humidified gas mixture (10.00 $\pm 0.01 \%$ oxygen in nitrogen) at $36^{\circ} \mathrm{C}$ for $50 \mathrm{~min}$. After hypoxia, the pups were returned to their dam until they were killed. In some experiments, mice were subjected to sham operation $14 \mathrm{~h}$ after saline or Poly I:C injection. In these cases, the animals were anesthetized as above and the left common carotid artery was exposed, but not ligated and the mice were not subjected to hypoxia.

Immunohistochemistry. Animals were anesthetized and intracardially perfused with saline and 5\% buffered formaldehyde (Histofix; Histolab) $5 \mathrm{~d}$ after Poly I:C/HI. Brains were rapidly removed and immersion fixed in $5 \%$ formaldehyde for $24 \mathrm{~h}$. After dehydration with graded series of ethanol and X-tra solv (Medite), brains were paraffin embedded and cut into $10 \mu \mathrm{m}$ frontal sections, from $\sim 1$ to $-2.0 \mathrm{~mm}$ of bregma, for immunohistochemical staining. Antigen recovery was performed by boiling the sections in $10 \mathrm{~mm}$ sodium citrate buffer, $\mathrm{pH}$ 6.0, for $10 \mathrm{~min}$. Nonspecific binding was blocked for $30 \mathrm{~min}$ in blocking solution (1\% horse serum, $3 \%$ bovine serum albumin, $0.1 \% \mathrm{NaN}_{3}$ in PBS). Sections were incubated in primary antibody against microtubule-associated protein-2 (MAP-2; clone HM-2, 1:1000; Sigma-Aldrich), mouse monoclonal antibody MBP (1:10,000, SMI-94R; Covance), or ionized calcium bindingadapter molecule 1 (Iba-1; 1:2000; Wako Chemicals) at $4^{\circ} \mathrm{C}$ overnight, followed by corresponding biotinylated secondary antibody (1:250; Vector Laboratories) for $60 \mathrm{~min}$ at room temperature. Visualization was performed using Vectastain ABC Elite (Vector Laboratories) with 0.5 $\mathrm{mg} / \mathrm{ml} \mathrm{3,3-diaminobenzidine} \mathrm{enhanced} \mathrm{with} 15 \mathrm{mg} / \mathrm{ml}$ ammonium nickel sulfate, $2 \mathrm{mg} / \mathrm{ml} \beta$-D-glucose, $0.4 \mathrm{mg} / \mathrm{ml}$ ammonium chloride, and $0.01 \mathrm{mg} / \mathrm{ml} \beta$-glucose oxidase (all from Sigma-Aldrich).

Brain injury evaluation. Brain gray and white matter injury and Iba-1positive microglia response were analyzed under a Nikon Optiphot-2 microscope equipped with an AVT dolphin F145B camera (Allied Vision Technologies) as shown previously (Svedin et al., 2007). An investigator blinded to the identity of the experimental groups performed all analyses.

For quantitative evaluation of gray matter injury, every 50th section throughout the brains was stained for MAP-2. Images were captured and processed using Micro Image version 4.0 (Olympus). Infarct area was assessed as the MAP-2-negative area in the ipsilateral (injured) hemisphere. Tissue loss was calculated by subtracting the MAP-2-positive volume of the ipsilateral hemisphere from the contralateral hemisphere, and brain injury was expressed as percentage tissue loss of the noninjured hemisphere (Svedin et al., 2007). Total infarct and tissue loss volumes were calculated according to the Cavalieri principle using the following formula: $V=\Sigma A \times P \times T$, where $V$ is total volume, $\Sigma A$ is the sum of areas measured, $P$ is the inverse of the sections sampling fraction, and $T$ is the section thickness (Roda et al., 1995; Svedin et al., 2007). Atrophy was calculated by subtracting the MAP-2 positive volume and infarct volume of the ipsilateral hemisphere from the total volume of the contralateral hemisphere.

In each sham-operated animal, the MAP-2-positive area of the left and right hemisphere was measured in two stained sections at the hippocampal level. 
White matter injury was analyzed by measuring the subcortical white matter area of positive staining for MBP (Micro Image version 4.0; Olympus) in both hemispheres at striatum and hippocampal levels. One section for each level was analyzed per animal. The MBP area in the ipsilateral hemisphere was compared with the contralateral hemisphere to calculate the proportion (percentage) of white matter damage.

In sham-operated animals, images of MBP-stained brain sections at two hippocampal levels were analyzed from each animal using NIH ImageJ (version 1.47f7). A region of interest (ROI; $4 \mathrm{~mm}^{2}$ ), including the subcortical white matter, was defined and applied to all sections. All images were converted to red-green-blue stack type, and a threshold for MBP staining was determined by the software. Within the ROI, the MBPstained area above the threshold was measured.

Quantitative reverse transcription-PCR. WT and TRIF KO mice were injected with Poly I:C $(10 \mathrm{mg} / \mathrm{kg})$ or LPS free saline at P8 and were killed at 6 and $14 \mathrm{~h}$ after injection (Fig. 1). Animals were anesthetized and intracardially perfused with saline, and brains were rapidly dissected out, snap frozen, and stored at $-80^{\circ} \mathrm{C}$ until analysis. Brain tissue was homogenized with Qiasol lysis reagent homogenizer (Qiagen), and total RNA was extracted using RNeasy Lipid Tissue Mini Kit (Qiagen) according to the instructions of the manufacturer. RNA was measured in a spectrophotometer at $260 \mathrm{~nm}$ absorbance. QuantiTect Reverse Transcription Kit (Qiagen) was used to synthesize first-strand cDNA according to the instructions of the manufacturer. Each PCR $(20 \mu \mathrm{l})$ contained $2 \mu \mathrm{l}$ of cDNA diluted 1:4, $10 \mu \mathrm{l}$ of Quanti Fast SYBR Green PCR Master Mix (Qiagen), $2 \mu \mathrm{l}$ of PCR primer, and $6 \mu \mathrm{l}$ of $\mathrm{H}_{2} \mathrm{O}$. The following primers were used: IFN- $\beta$ (QT00249662), IL-6 (QT00098875), IL-1 $\beta$ (QT01048355), monocyte chemoattractant protein-1 (MCP-1) (QT00167832), interferon-induced protein-10 (IP-10) (QT00093436), TNF- $\alpha$ (QT00104006), IL-10 (QT00106169), Fas (QT00095333), GAPDH (QT01658692), and tyrosine 3-monooxygenase/tryptophan 5-monooxygenase activation protein, zeta polypeptide (YWHAZ; QT00105350) (all from Qiagen).

The amplification protocol comprised an initial $5 \mathrm{~min}$ denaturation at $95^{\circ} \mathrm{C}$, followed by 40 cycles of denaturation for $10 \mathrm{~s}$ at $95^{\circ} \mathrm{C}$ and annealing/extension for $30 \mathrm{~s}$ at $60^{\circ} \mathrm{C}$ on a LightCycler 480 (Roche). Meltingcurve analysis was performed to ensure that only one PCR product was obtained. For quantification and for estimating amplification efficiency, a standard curve was generated using increasing concentrations of cDNA. The amplification transcripts were quantified with the relative standard curve and normalized against the geometric mean of the reference genes GAPDH and YWHAZ.

Phospho-protein analyses. WT mice were injected with Poly I:C (10 $\mathrm{mg} / \mathrm{kg}$ ) or LPS free saline at P8 and were killed at 1 and $6 \mathrm{~h}$ after injection (Fig. 1). Animals were anesthetized and intracardially perfused with saline, and brains were rapidly dissected out, snap frozen, and stored at $-80^{\circ} \mathrm{C}$ until analysis. Samples were prepared for phospho-protein analysis with Bio-Plex Cell Lysis Kit (catalog \#171-304011; Bio-Rad) according to the protocol from the manufacturer. Protein concentration was measured with BCA protein assay (Thermo Fisher Scientific) and adjusted to $450 \mu \mathrm{g} / \mathrm{ml}$. For detection of phosphorylation of proteins, BioPlex Phospho 5-Plex Panel (X7000001RD; Bio-Rad) was used according to the instructions of the manufacturer and analyzed on a Bio-Plex 200 system (Bio-Rad) with the Bio-Plex Manager software 6.0 (Bio-Rad). The changes in phosphorylation were calculated using a ratio between mean fluorescence of phosphorylated protein and total protein.

Post-injury flow cytometry analysis of microglia. Animals were deeply anesthetized and intracardially perfused with saline at $24 \mathrm{~h}$ after saline/HI and Poly I:C/HI or saline/sham and Poly I:C/sham (Fig. 1). Brains were dissected out and placed in Hibernate A (A12475-01; Invitrogen). Cells from the injured and uninjured hemispheres were homogenized in CellWASH (catalog \#349524; BD Biosciences) using a glass homogenizer. After filtration through a $100 \mu \mathrm{m}$ cell strainer, samples were washed three times $\left(340 \times g, 5 \mathrm{~min}, 4^{\circ} \mathrm{C}\right)$ and resuspended in CellWASH. Cells were counted with a TC10 automated cell counter (Bio-Rad), and $1 \times 10^{6}$ cells from each sample were used for immunostaining.

After incubation with anti-CD16/32 Fc-receptor block $\left(1 \mu \mathrm{g} / 10^{6}\right.$ cells; catalog \#553142; BD Biosciences Pharmingen), samples were stained with antibodies for microglia marker CD11b (anti-mouse CD11b Alexa Fluor 488; eBioscience), M1 marker CD86 (adenomatous polyposis coli anti-mouse CD86; Biolegend), and M2 marker CD206 (phycoerythrin anti-mouse CD206; Biolegend), all at a concentration of $0.5 \mu \mathrm{g} / 10^{6}$ cells, for $30 \mathrm{~min}$. Cells were washed and resuspended in CellWASH. 7-Aminoactinomycin D (7AAD; catalog \#51-68981E; BD Biosciences Pharmingen) was added to each sample to distinguish between alive and dead cells. Samples were kept on ice through the whole procedure. Flow cytometric data were collected on an FACSCantoAflow cytometer (BD Biosciences) and analyzed using FACSDiva Software version 6.1.3 (BD Biosciences). For analysis, cells of interest were identified (P1 gate) in forward and side scatter. From the P1 gate, 7AAD was used to define dead cells, and the $\mathrm{CD} 11 \mathrm{~b}^{+}$cells were then gated on live cells. For gating strategy, see Figure $7 \mathrm{~A}$. Approximately $2 \times 10^{5}$ live cells were analyzed from each brain hemisphere. The same gates were used on all samples run simultaneously.

Statistics. Brain injuries were analyzed with two-way ANOVA with genotype and treatment or treatment and time point as factors, followed by Bonferroni's post hoc test with a $95 \%$ confidence interval. Brain injury in WT sham-operated animals with or without Poly I:C injection was compared by Student's $t$ test. Gene expression data were analyzed with one-way ANOVA, followed by Bonferroni's post hoc test with a $95 \%$ confidence interval. WT and TRIF KO data were analyzed separately. Phospho-proteins were analyzed with Student's $t$ test between Poly I:C and saline for each time point separately. Flow cytometry data were analyzed with a one-way ANOVA, followed by Newman-Keuls multiple comparison test with a $95 \%$ confidence interval. Data are presented as mean \pm SEM, and significance was set at $p<0.05$. All statistical analyses were performed using GraphPad Prism 5.0 (GraphPad Software).

\section{Results}

\section{Poly I:C increases the vulnerability of the neonatal brain} to $\mathrm{HI}$

To investigate the Poly I:C effect alone on neonatal gray and white matter development, saline or Poly I:C was administered $14 \mathrm{~h}$ before sham surgery. No significant difference in the area of MAP-2 or MBP staining was demonstrated in Poly I:C-injected animals compared with saline-injected animals $5 \mathrm{~d}$ after sham surgery (data not shown). To examine the role of TLR-3 activation on neonatal HI brain injury, Poly I:C or saline was administered $14 \mathrm{~h}$ before HI (Poly I:C/HI and saline/HI groups, respectively) in neonatal mice, and neuropathological analyses of gray and white matter injury were performed $5 \mathrm{~d}$ after HI. In WT mice, Poly I:C pretreatment increased HI-induced infarct volume (Poly I:C/HI, $15.40 \pm 2.06 \mathrm{~mm}^{3}, n=20$ vs saline/HI, $3.01 \pm$ $0.49 \mathrm{~mm}^{3}, n=21, p<0.001$; Fig. $2 A, B$ ), tissue loss (Poly IC/HI, $48.9 \pm 2.62 \%, n=20$ vs saline/HI: $25.62 \pm 2.07 \%, n=21, p<$ 0.001; Fig. 2C,D), and atrophy (Poly I:C/HI, $28.83 \pm 1.83 \mathrm{~mm}^{3}$, $n=20$ vs saline/HI, $\left.20.57 \pm 1.44 \mathrm{~mm}^{3}, n=21, p<0.01\right)$. Immunohistochemistry staining for neuronal marker MAP-2 in brain sections revealed that injury was confined to the ipsilateral hemisphere and mainly distributed in the hippocampus, cortex, striatum, and thalamus (Fig. 2E).

Compared with the saline/HI group, Poly I:C/HI mice showed more severe white matter injury as indicated by significantly increased loss of immunostaining for MBP in the subcortical white matter at both the hippocampal level (Poly I:C/HI, $70.60 \pm$ $5.33 \%$ loss, $n=20$ vs saline/HI, $13.38 \pm 6.00 \%$ loss, $n=21, p<$ 0.001; Fig. $3 A, C$ ) and striatum level (Poly I:C/HI, $67.85 \pm 3.67 \%$ loss, $n=20$ vs saline/HI, $27.71 \pm 2.62 \%$ loss, $n=21, p<0.001$; Fig. $3 B$ ) at $5 \mathrm{~d}$ after HI.

There was no difference in either gray or white matter injury between WT and TRIF KO mice after saline/HI ( $p>0.05$; Figs. 2, 3). The sensitizing effect of Poly I:C to HI was blocked in TRIF $\mathrm{KO}$ mice, and there was no significant difference in any of the brain injury parameters between saline- and Poly I:C-treated TRIF KO animals ( $p>0.05$; Figs. 2, 3). 
A

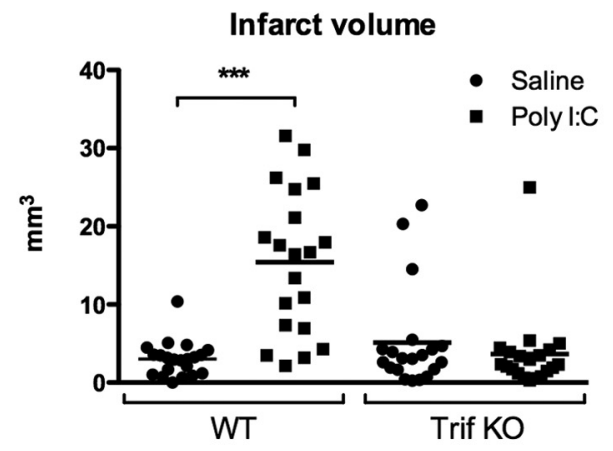

C

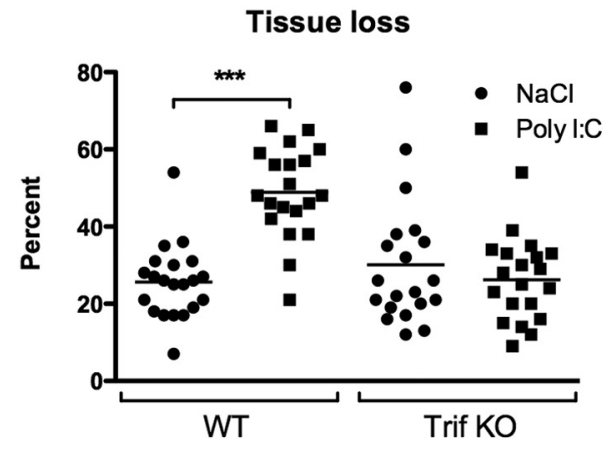

E

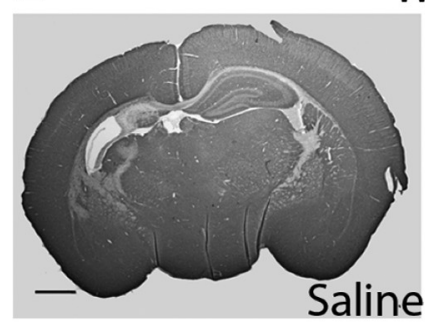

WT
B Infarct

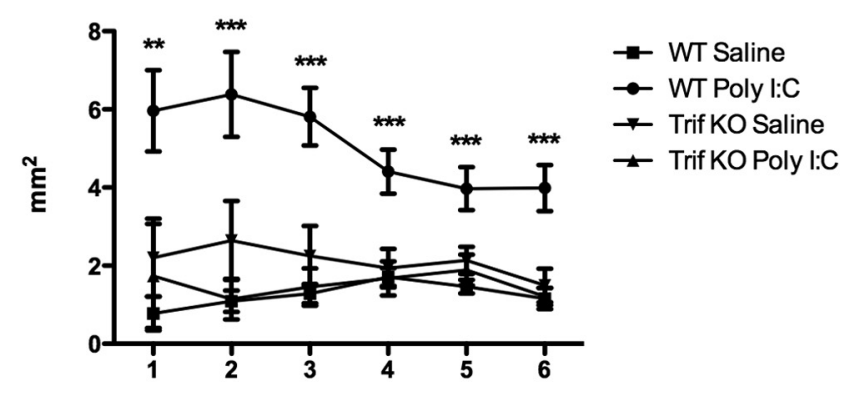

D

Tissue loss

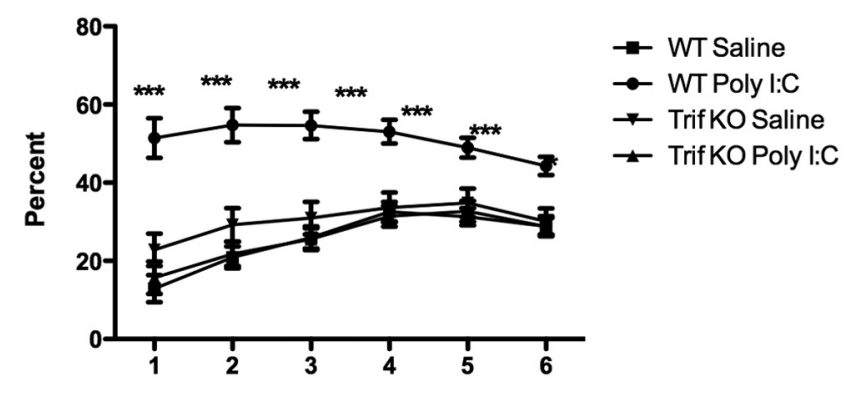

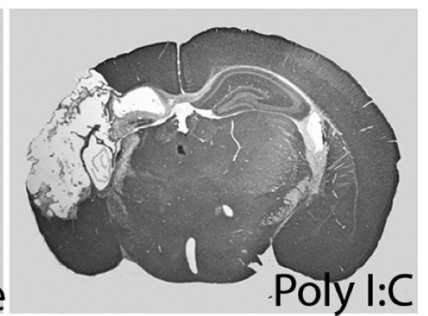

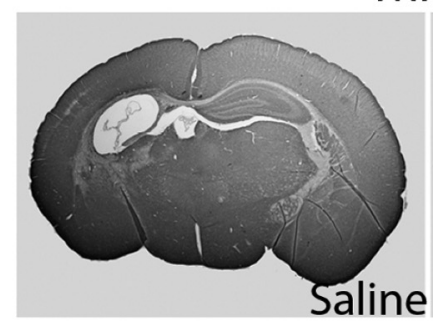

Trif KO

Figure 2. TLR-3 activation sensitize the brain to HI. Neuropathological analysis at $5 \mathrm{~d}$ after HI showed a significant increase in both infarct volume $(\boldsymbol{A})$ and tissue loss $(\boldsymbol{C})$ in Poly l: $(-$-treated WT mice compared with saline/HI mice. In WT mice, the infarct area at 6 levels of the brain $(\boldsymbol{B})$ and tissue loss $(\boldsymbol{D})$ were significantly increased throughout the brain in Poly I: $\mathrm{C} / \mathrm{HI}$ compared with saline/HI animals. In TRIF KO mice, no differences were found between poly I:C/HI and saline/HI animals. $E$, Representative images of MAP-2-stained sections in WT and TRIF KO mice $5 \mathrm{~d}$ after saline/HI and Poly I:C/HI. Anteroposterior levels, from $\sim 1$ to $-2 \mathrm{~mm}$ of bregma, are indicated by numbers in $\boldsymbol{B}$ and $\boldsymbol{D}$, where level 1 indicates the most posterior level. Data are presented as mean \pm SEM. ${ }^{* *} p \leq$ $0.01,{ }^{* * *} p \leq 0.001 ; n=20-21$ per group. Scale bar: $\boldsymbol{E}, 1 \mathrm{~mm}$.

The inflammatory response as indicated by Iba-1 immunostaining showed a typical pattern of amoeboid-like cells in injured brain regions (Fig. 4). The degree and distribution of Iba-1 expression correlated with the degree of brain damage in all experimental groups. The morphology of the Iba-1-positive cells in injured areas did not differ between Poly I:C/HI- or saline/HItreated animals or between genotypes (Fig. 4).

\section{Poly I:C induces inflammatory genes in the brain in a} TRIF-dependent manner

To elucidate Poly I:C-mediated factors that may contribute to the increased vulnerability to $\mathrm{HI}$, we analyzed genes associated with apoptosis (Fas), proinflammatory and anti-inflammatory immune responses (IL-6, IL- $1 \beta$, TNF- $\alpha$, IFN- $\beta$, and IL-10), and chemotaxis (IP-10 and MCP-1) in the brain after Poly I:C administration. The expression of IL-10 was below detection level in both WT and TRIF KO mice at both time points (data not shown).

In WT mice, Poly I:C upregulated levels of IL- 6 mRNA at $6 \mathrm{~h}$ $(n=10, p<0.001$; Fig. $5 A)$, IL- $1 \beta$ mRNA expression at $14 \mathrm{~h}(n=$ $10, p<0.001$; Fig. $5 B)$, TNF- $\alpha$ at $6 \mathrm{~h}(n=10, p<0.05)$ and $14 \mathrm{~h}$ $(n=10, p<0.001$; Fig. $5 C)$, and IFN- $\beta$ at $6 \mathrm{~h}(n=4, p<0.05)$ and $14 \mathrm{~h}(n=5, p<0.001$; Fig. $5 D)$. Poly I:C also modulated the chemokine response shown by upregulation of IP-10 at $6 \mathrm{~h}(n=$ $10, p<0.001$; Fig. $5 E)$ and MCP-1 at $6 \mathrm{~h}(n=10, p<0.001)$ and $14 \mathrm{~h}(n=10, p<0.001$; Fig. $5 F)$. Fas mRNA expression was upregulated at $6 \mathrm{~h}(n=10, p<0.001$; Fig. $5 G)$. The Poly I:Cinduced inflammation for all the analyzed genes was blocked in TRIF KO mice (Fig. 5A-G).

Poly I:C induces phosphorylation of nuclear factor $\kappa \mathrm{B}$ inhibitor and reduces $\mathrm{pAKT}$ phosphorylation

Poly I:C-induced cytokine production may be regulated through mitogen-activated protein kinases (MAPKs) (Kim et al., 2008; Liu et al., 2008). To further investigate the Poly I:C sensitizing mechanism downstream of TLR-3/TRIF, we analyzed the phosphorylation of ERK, JNK, and p38 and also the pro-survival serine/threonine-specific protein kinase Akt and the general inflammatory conductor nuclear factor $\kappa \mathrm{B}$ inhibitor $(\mathrm{I} \kappa \mathrm{B})$. Poly $\mathrm{I}: \mathrm{C}$ administration downregulated the phosphorylation of Akt at $1 \mathrm{~h}(n=8, p<0.05$; Fig. $6 A)$, whereas phosphorylation of I $\kappa \mathrm{B}$ increased at $1 \mathrm{~h}(n=8, p<0.01$; Fig. $6 B)$. There were no differ- 
A

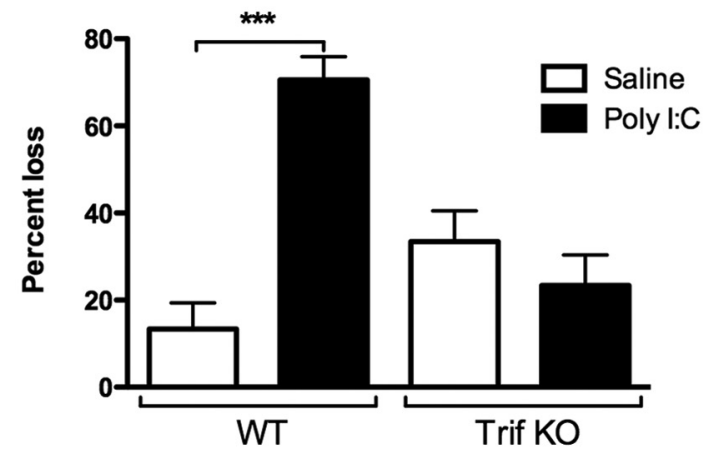

C
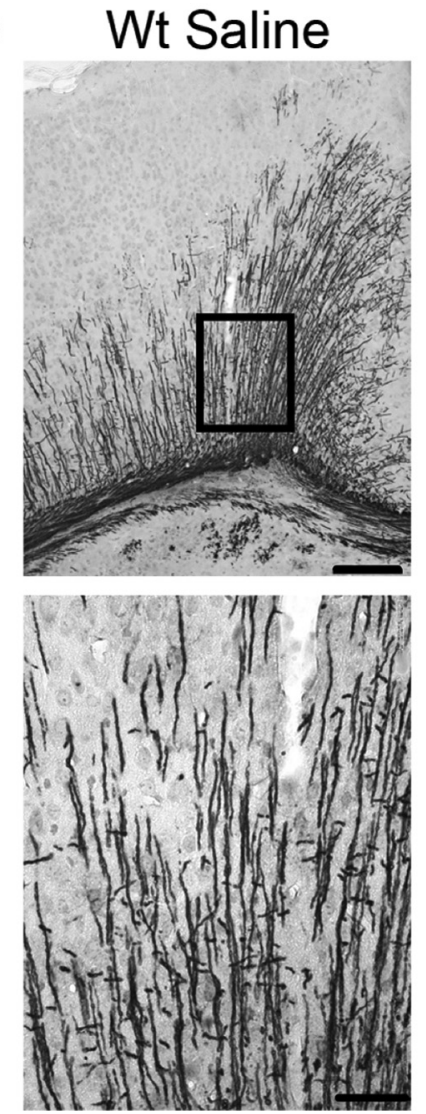

B

\author{
Striatum level
}
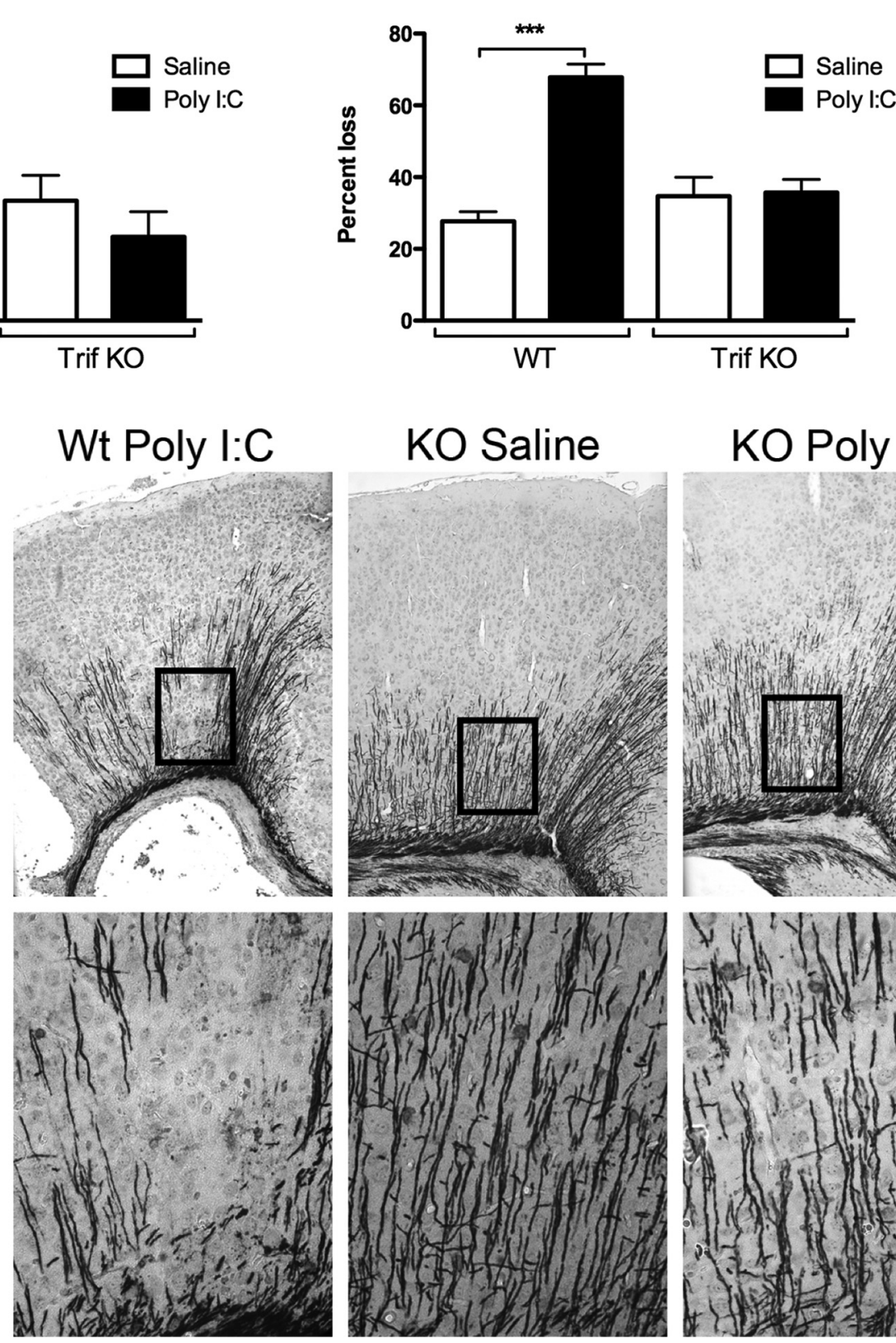

KO Saline

KO Poly l:C
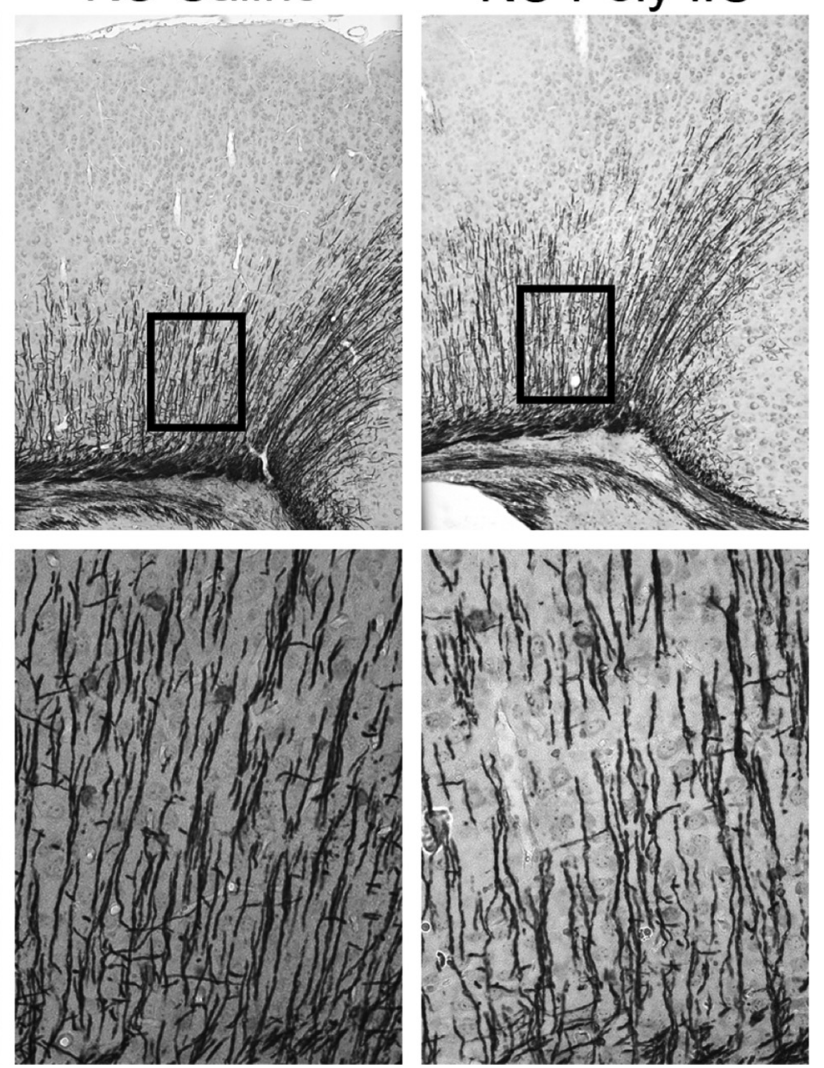

Figure 3. Effects of TLR-3 activation on white matter injury. In WT mice, white matter injury was increased in Poly I:C/HI WT mice compared with saline/HI at both the hippocampal (A) and striatum (B) levels. No differences were seen between treatment groups in the TRIF KO mice. $C$, Representative images of MBP-stained sections in WT and TRIF KO mice after Poly I:C/HI or saline/HI at the hippocampal level. Data are shown as mean \pm SEM percentage loss of MBP stain. ${ }^{* *} p \leq 0.001 ; n=20-21$ per group. Insets represent the area that is depicted at higher magnification. Scale bars: top, $20 \mu \mathrm{m}$; bottom, $5 \mu \mathrm{m}$.

ences in phosphorylation of ERK, JNK, or p38 between Poly I:Cand saline-treated animals at any of the analyzed time points (Fig. $6 D, E)$.

Poly I:C reduces reparative "M2-like" microglia after $\mathrm{HI}$ To evaluate the inflammatory response after Poly I:C/HI, the microglia response was analyzed by flow cytometry. We investigated the general population of microglia by examining CD11b ${ }^{+}$ cells. These cells were further classified as either proinflammatory (M1) or anti-inflammatory/reparative (M2) phenotypes (Colton, 2009), using markers CD86 and CD206, respectively. The overall population of $\mathrm{CD} 11 \mathrm{~b}^{+}$microglia increased in the ipsilateral hemisphere compared with the contralateral hemisphere in
Poly I:C/HI animals (Poly I:C/HI ipsilateral hemisphere, $1.06 \pm$ $0.09 \%$ vs Poly I:C/HI contralateral hemisphere, $0.60 \pm 0.13 \%$, $n=9$ per group, $p<0.05$; Fig. $7 B$ ) but not in saline/HI mice ( $p>$ 0.05 ; Fig. $7 B)$. Within the $C D 11 b^{+}$population, two different populations were distinguished: (1) a CD11 $\mathrm{b}^{\text {thigh }}$-expressing and (2) a CD11 $\mathrm{b}^{+ \text {low }}$-expressing population, which were both affected by $\mathrm{HI}$ but not by Poly I:C alone (saline CD11b $\mathrm{b}^{\text {thigh }}$, $3.70 \pm 0.71 \%$ vs Poly I:C CD11b $\mathrm{b}^{\text {thigh }}, 2.67 \pm 0.38 \%$; saline $\mathrm{CD}_{11 b^{+ \text {low }}}, 94.24 \pm 1.03 \%$ vs Poly I:C CD11b ${ }^{+ \text {low }}, 96.14 \pm$ $0.52 \%, n=7$ per group). The $\mathrm{CD} 11 \mathrm{~b}^{\text {thigh }}$ population increased in the injured hemisphere in both saline/HI-treated (ipsilateral hemisphere, $42.00 \pm 3.88 \%$ vs contralateral hemisphere, $5.07 \pm$ $1.39 \%, n=8$ per group, $p<0.001$ ) and Poly I:C/HI-treated (ipsi- 
lateral hemisphere, $24.54 \pm 4.86 \%$ vs contralateral hemisphere, $6.26 \pm 1.64 \%, n=9$ per group, $p<0.001$ ) animals (Fig. $7 B$ ). In contrast, the $\mathrm{CD} 11 \mathrm{~b}^{\text {+low }}$ population was decreased in the injured hemisphere in both saline/HI-treated (ipsilateral hemisphere, $54.98 \pm 3.88 \%$ vs contralateral hemisphere, $93.63 \pm 1.79 \%, n=8$ per group, $p<0.001$ ) and Poly I:C/HI-treated (ipsilateral hemisphere, $70.39 \pm 5.58 \%$ vs contralateral hemisphere, $91.77 \pm 1.81 \%$, $n=9$ per group, $p<0.001$; Fig. $7 B$ ) animals. The CD11b ${ }^{\text {thigh }}$ population in the injured hemisphere was significantly lower in Poly $\mathrm{I}: \mathrm{C} / \mathrm{HI}$ compared with saline/HI animals $(p<0.001)$, whereas the CD11b ${ }^{\text {low }}$ population was significantly higher in the injured hemisphere after Poly I:C/HI compared with saline/HI $(p<0.01)$. Representative dot plots of high and low populations of $\mathrm{CD} 1 \mathrm{~b}^{+}$cells are illustrated in Figure $7 B$.

Additional analysis of the $\mathrm{CD}_{11 \mathrm{~b}^{+}} \mathrm{mi}-$ croglia cells into M1-like (proinflammatory) and M2-like (reparative) phenotypes were performed by using CD86 as an M1 marker and CD206 as an M2 marker. There were no significant changes in M1-like $\mathrm{CD}_{11 \mathrm{~b}}{ }^{+} \mathrm{CD} 86^{+}$cells in the ipsilateral compared with the contralateral hemisphere after either Poly I:C/HI or saline/HI $(p>0.05$; Fig. $7 C$ ). In contrast, there was a decrease in $\mathrm{M} 2$-like $\mathrm{CD}_{11 \mathrm{~b}}{ }^{+} \mathrm{CD} 206^{+}$cells in the injured hemisphere in both saline/HI (ipsilateral hemisphere, $8.3 \pm 1.45 \%$ vs contralateral hemisphere, $29.98 \pm 4.66 \%$, $n=8$ per group, $p<0.001)$ and Poly I:C/HI (ipsilateral hemisphere, $3.49 \pm 0.67 \%$ vs contralateral hemisphere, $14.57 \pm 1.73 \%$, $n=9$ per group, $p<0.01$; Fig. $7 C$ ) animals. In the contralateral hemisphere, the percentage of $\mathrm{CD} 11 \mathrm{~b}^{+} \mathrm{CD} 206^{+}$cells was lower in Poly I:C/HI animals compared with saline/HI mice $(p<0.001)$. Similarly, the population of $\mathrm{CD} 11 \mathrm{~b}^{+} \mathrm{CD} 206^{+}$cells was reduced in sham-operated animals pretreated with Poly I:C $(11.14 \pm 0.76 \%, n=7)$ compared with saline pretreated pups $(24.96 \pm 3.99 \%, n=7, p<0.01)$.

\section{Discussion}

Infections by themselves or in combination with other insults are major risk factors for perinatal brain injury, but the precise etiology is often unclear. In the current study, we provide novel data to show that activation of the viral innate immune receptor TLR-3 sensitizes the neonatal brain to subsequent hypoxic-ischemic damage in a TRIF-dependent manner. The increased vulnerability to HI was associated with a TRIFdependent heightened inflammatory response, including proinflammatory cytokine and chemokine expression and altered characteristics of CD $11 b^{+}$microglia in the brain. Cell death/ survival pathways were also affected with an increase in expression of the apoptosis-associated mediator Fas, whereas
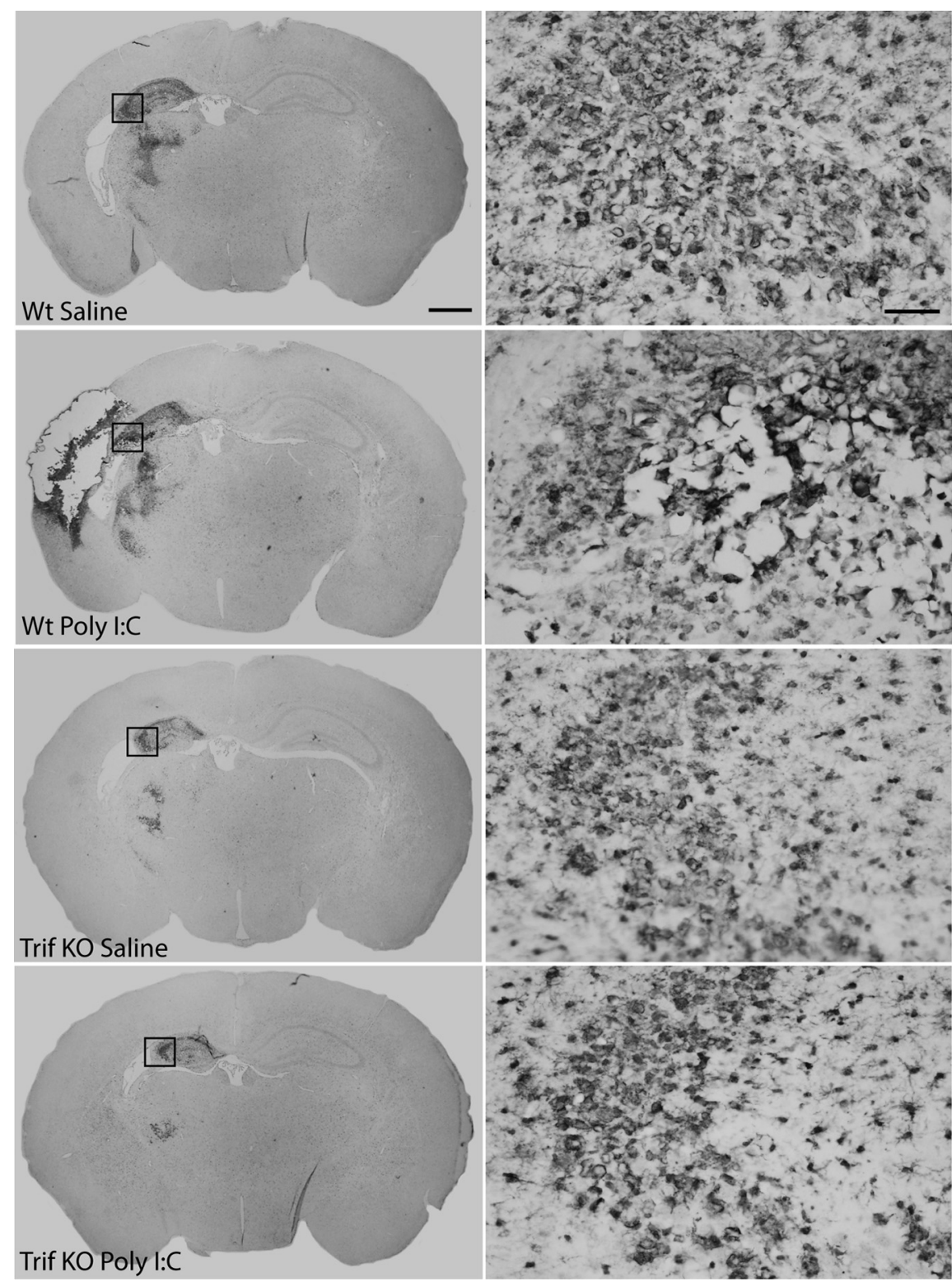

Figure 4. Inflammatory response after HI. The inflammatory response, as indicated by lba-1 immunostaining, showed a pattern of amoeboid-like cells in injured brain regions. The degree and distribution of lba-1 expression appeared to correlate to the degree of brain damage in all experimental groups. The morphology of the lba-1-positive cells in injured areas did not differ between Poly I:C/HI-treated $(\boldsymbol{B}, \boldsymbol{D})$ or saline/HI-treated $(\boldsymbol{A}, \boldsymbol{C})$ animals or between genotypes. Insets represent the area that is depicted at higher magnification. Scale bars: left, $1 \mathrm{~mm}$; right, $5 \mu \mathrm{m}$.

pro-survival pathways, such as phosphorylation of Akt, were reduced.

In adult animals, neither TLR-3 or TRIF deficiency provide protection against cerebral ischemia (Hua et al., 2009; Hyakkoku et al., 2010; Famakin et al., 2011). The present results, showing no difference in brain injury in WT or TRIF KO neonatal animals after saline/HI, coincide well with previous findings in adult ischemia models. In the adult brain, poly I:C exacerbates the inflammatory response and neurodegeneration (Field et al., 2010) and increases the susceptibility of midbrain dopaminergic neurons to subsequent neurotoxicity (Deleidi et al., 2010). These data imply that activation of TLR-3 increases the vulnerability of the brain to additional insults. However, previous stimulation of the TRIF pathway, via activation of TLR-4, confers protection against subsequent ischemic injury by reprogramming the response of the 

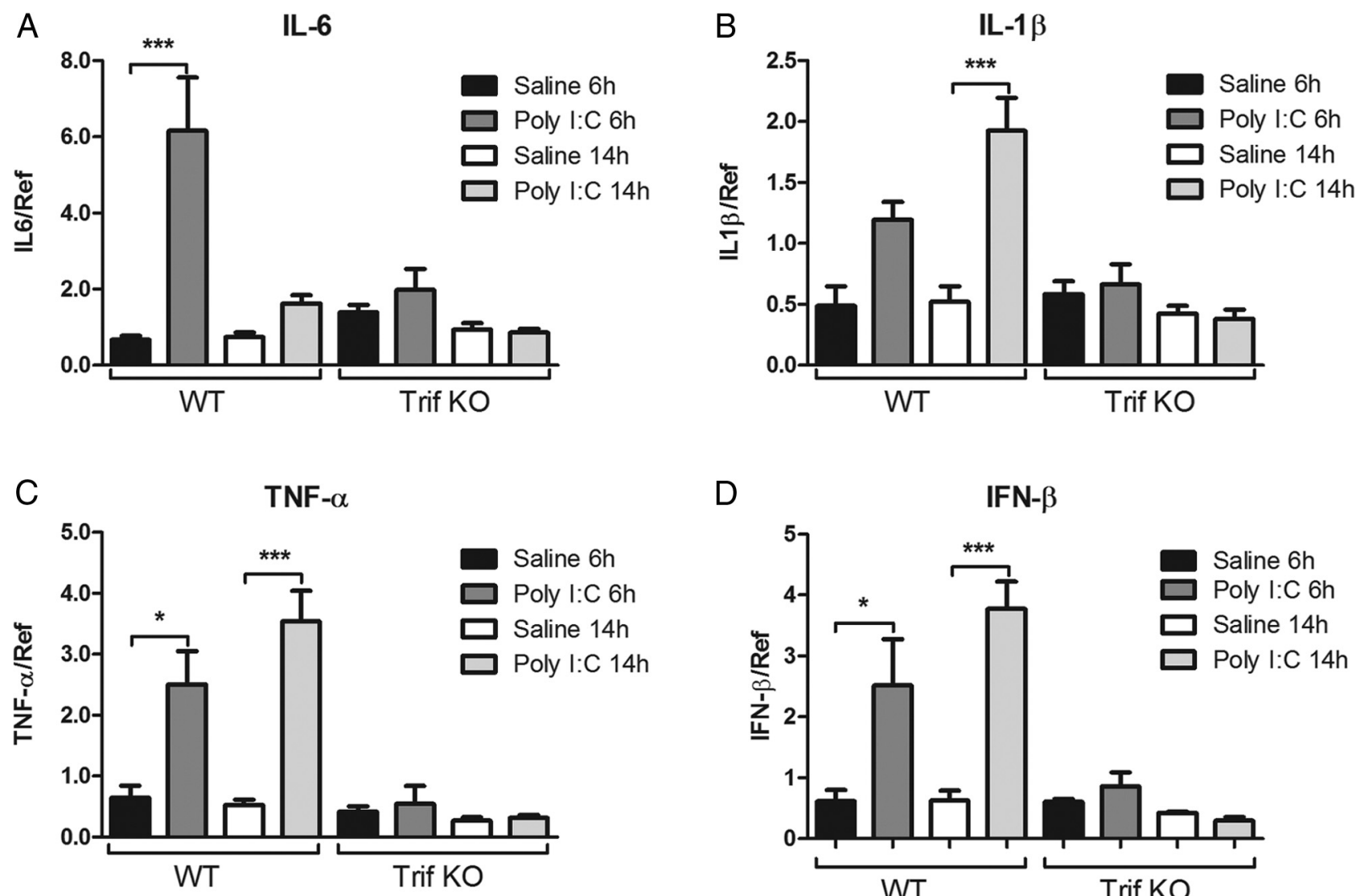

$\mathrm{D}$

IFN- $\beta$

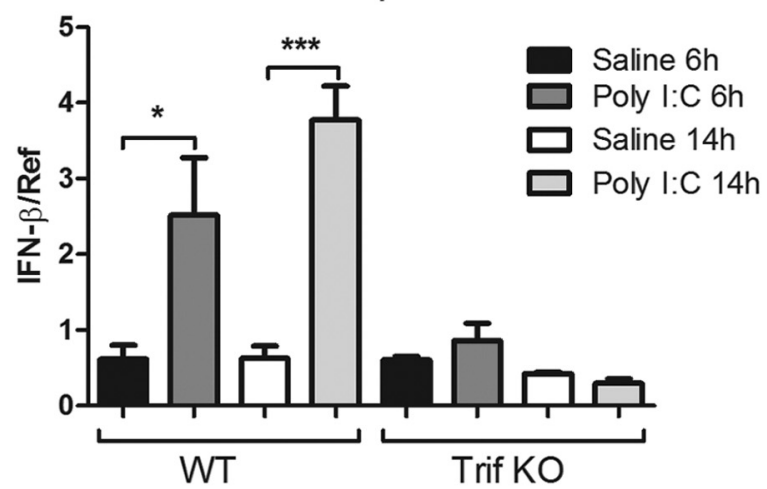

$\mathrm{E}$

IP-10

$\mathrm{F}$
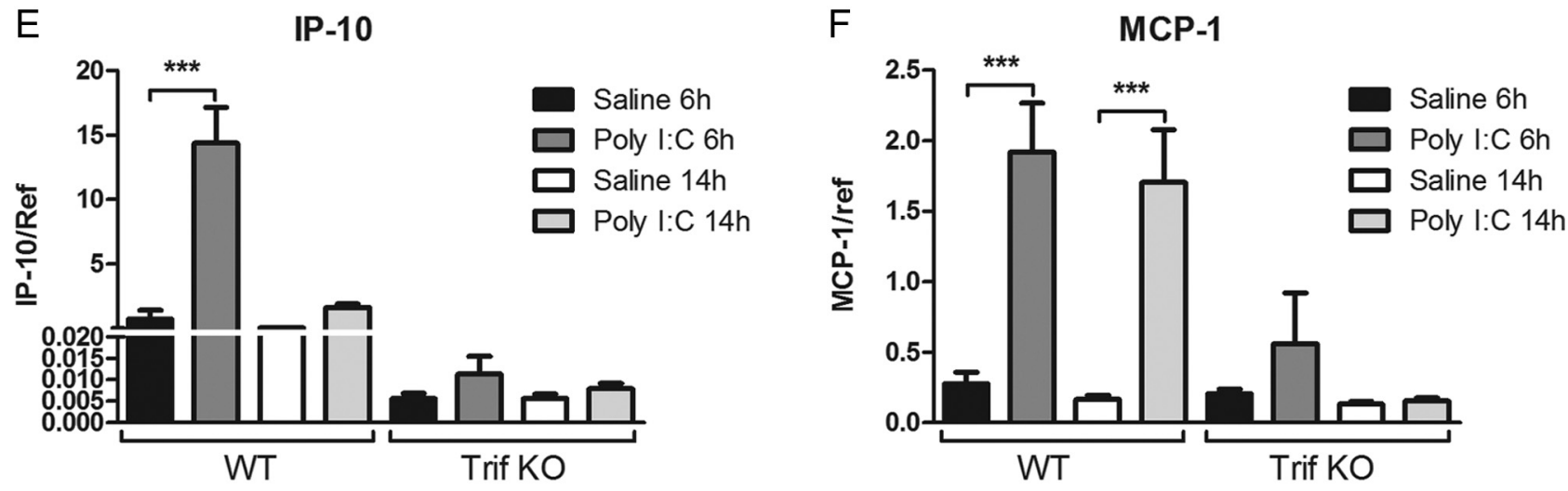

G

Fas

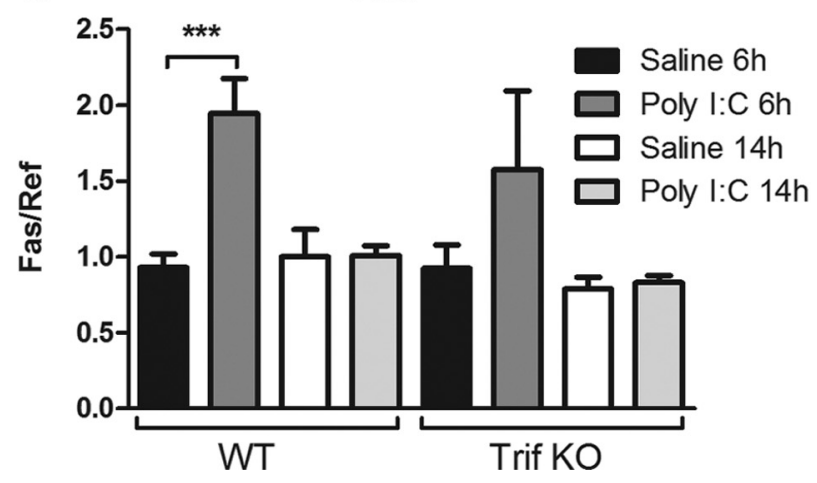

Figure 5. Gene expression analysis after Poly I:C administration. In WT mice, Poly I:C (10 mg/kg) increased mRNA expression of IL-6at $6 \mathrm{~h}(\boldsymbol{A}), \mathrm{IL}-1 \beta$ at $14 \mathrm{~h}(\boldsymbol{B})$, TNF- $\alpha$ at both 6 and $14 \mathrm{~h}(\boldsymbol{C})$, IFN- $\beta$ at both 6 and $14 \mathrm{~h}(\boldsymbol{D}), \mathrm{PP}-10$ at $6 \mathrm{~h}(\boldsymbol{E}), \mathrm{MCP}-1$ at both 6 and $14 \mathrm{~h}(\boldsymbol{F})$, and Fas at $6 \mathrm{~h}(\boldsymbol{G})$ compared with controls (saline). In TRIF $\mathrm{K} 0$ animals, there were no differences in expression of any of the genes between Poly I:C- and saline-injected mice. Data are presented as mean $\pm \mathrm{SEM} ;{ }^{*} p \leq 0.05$, ${ }^{* * *} p \leq 0.001, n=7-10$ per group. 
A

Akt

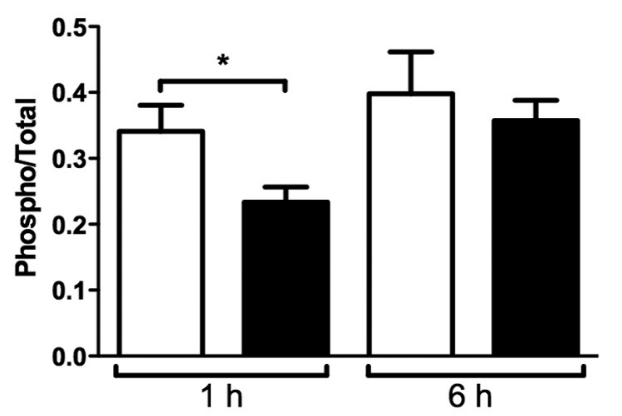

C

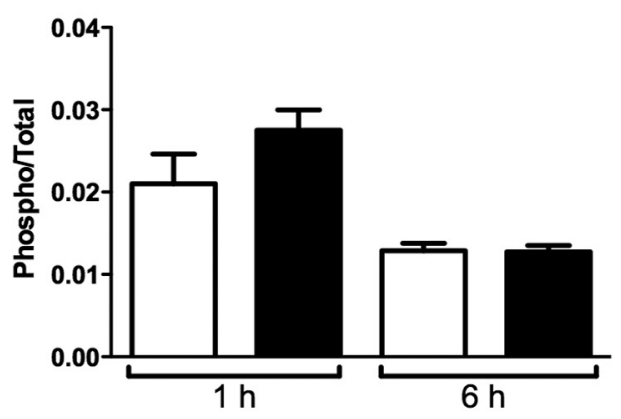

E

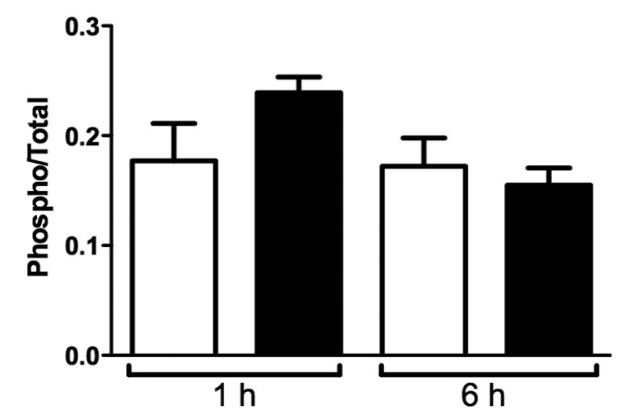

B

IkB

$\mathrm{NaCl}$

Poly I:C

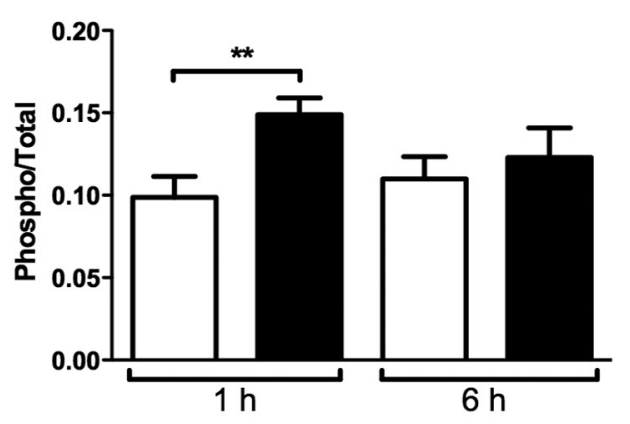

D

P38

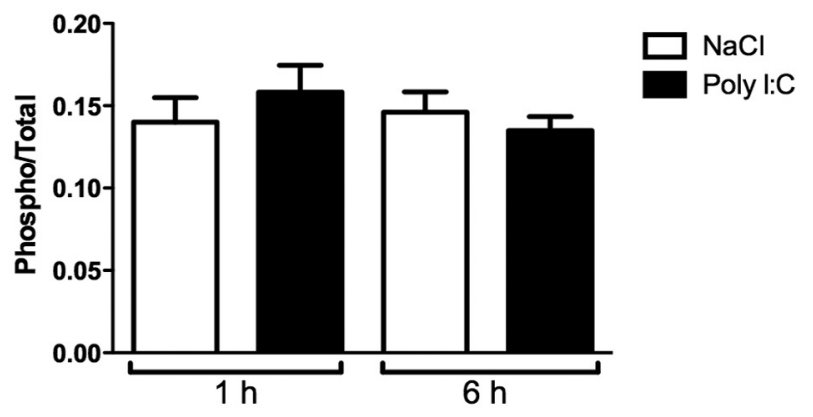

Figure 6. Poly I:C effects on MAPK and I $\boldsymbol{\kappa} B$ phosphorylation. In WT mice, Poly I:C (10 mg/kg) reduced the phosphorylation of Akt at $1 \mathrm{~h}(A)$, whereas phosphorylation of $\mid \kappa B$ was increased at $1 \mathrm{~h}$ (B). There were no changes in the phosphorylation of ERK, JNK, or $\mathrm{p} 38(\boldsymbol{C}-\boldsymbol{E})$. Data are presented as mean $\pm \mathrm{SEM} ;{ }^{*} p \leq 0.05,{ }^{* *} p \leq 0.01 ; n=8$ per group.

adult brain to stroke via a TRIF/interferon regulatory factor-3 (IRF-3)-induced IFN- $\beta$ pathway (Marsh et al., 2009). In later studies, it was also shown that Poly I:C acts as a preconditioning factor before cerebral ischemia (Packard et al., 2012). Here, neonatal $\mathrm{HI}$ is produced at the time point of maximum induction of IFN- $\beta$ by Poly I:C (14 h). However, despite the increased level of IFN- $\beta$ expression in the brain at the time of $\mathrm{HI}$, we were unable to detect any TLR3/TRIF-mediated neuroprotection. The discrepancy between our results and those in adult animals may be attributable to differences in the time interval between Poly I:C and the cerebral ischemic insult. We showed previously that activation of TLR-4, by LPS, $14 \mathrm{~h}$ before HI increases the vulnerability to neonatal brain injury (Wang et al., 2009) and that the time interval between immune stimulation and HI was critical for neuropathological outcome (Eklind et al., 2005). Conversely, the developmental stage at the time of TLR-3/TRIF activation may also affect outcome. The developing brain appears to be particularly sensitive to TLR-3 stimulation (Meyer et al., 2006; Ratnayake et al., 2012). Furthermore, we have evidence that TLR-3 expression in glia and neurons is altered in response to white matter injury in preterm human infants (Vontell et al., 2013), suggesting that TLR-3 may serve important functions during brain development. These studies are in agreement with the marked increased vulnerability to HI observed in the current study after previous Poly I:C administration. Together, these findings strongly suggest that activation of TLR-3/TRIF is detrimental to the developing brain, especially when followed by another insult to the brain.

Signaling through TLR-3 is mediated through the adaptor protein TRIF. Both the C- and N-terminal domains of TRIF can associate with several intracellular proteins, including receptorinteracting protein-1, TNF receptor-associated factor-6, and serine/threonine protein kinase-1, mediating activation of both nuclear factor $-\kappa \mathrm{B}(\mathrm{NF}-\kappa \mathrm{B})$ and IRF-3 regulated genes as well as apoptotic pathways through FAS-associated death domain and caspase-8 (Sato et al., 2003; McWhirter et al., 2004; Meylan et al., 2004; Cusson-Hermance et al., 2005; Sasai et al., 2005). To evaluate inflammatory responses in the neonatal brain after Poly I:C, 
A

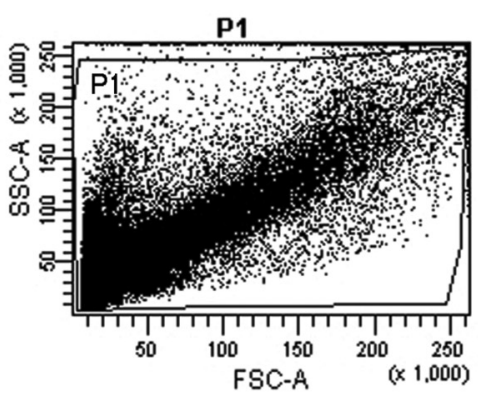

B

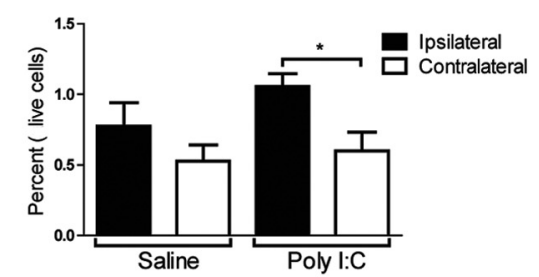

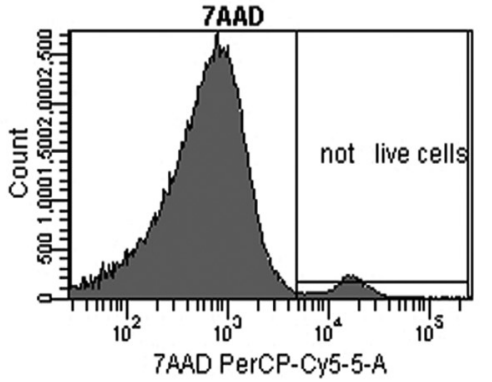

CD11b+ high population

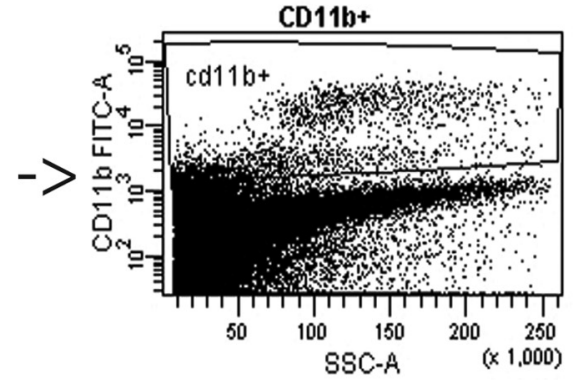

CD11b+ low population
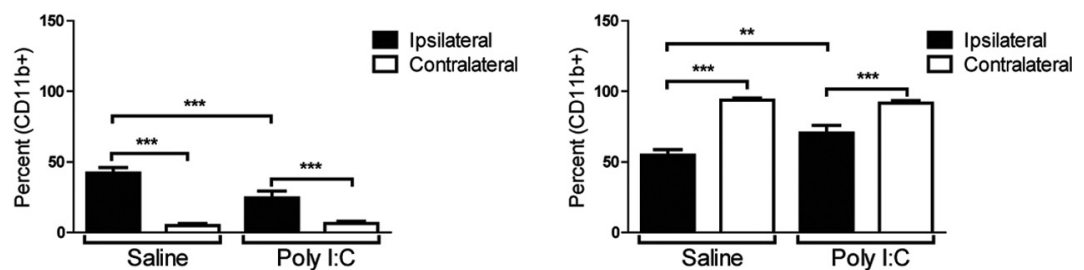

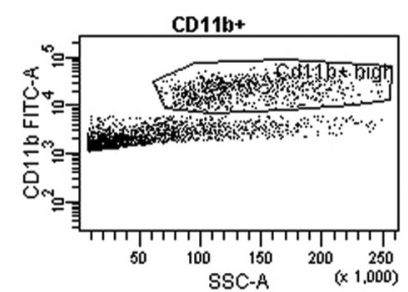

Saline Ipsilateral

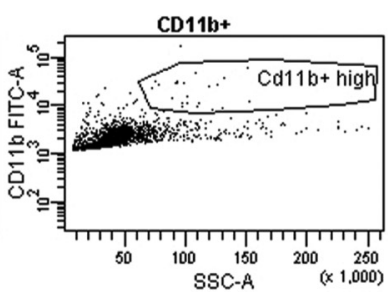

Saline Contralateral

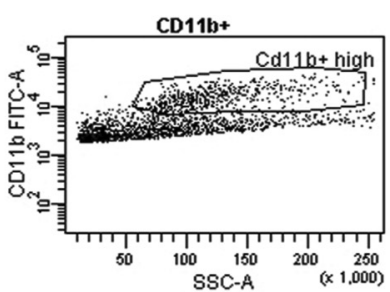

Poly I:C Ipsilateral

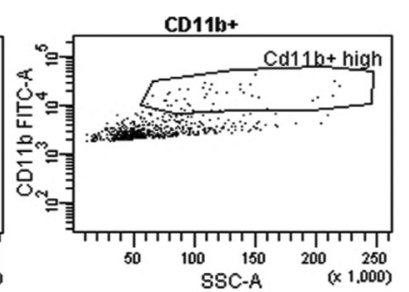

Poly I:C Contralateral
C

CD11b+CD86+

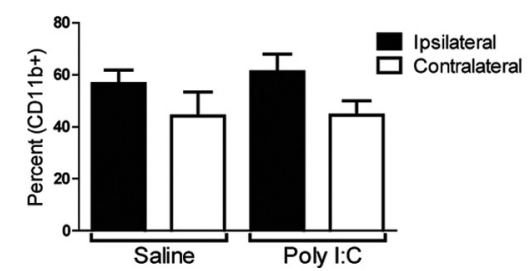

CD11b+CD206+

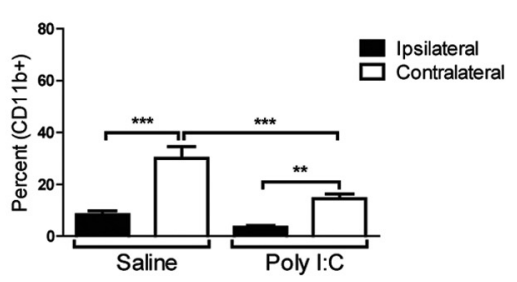

Figure 7. Poly I:C reduces reparative M2-like microglia after hypoxic-ischemic injury. $A$, Gating strategy for analysis of $C D 11 b^{+}$microglia cells. A P1 gate was defined in forward and side scatter. $7 A A D$ was used to distinguish between live and dead cells, and microglia marker CD11b was then gated from the live cells. $\boldsymbol{B}$, The overall population of CD11b ${ }^{+}$microglia increased in the ipsilateral hemisphere compared with the contralateral hemisphere in Poly I:C/HI animals but not in saline/HI mice. Within the CD11b ${ }^{+}$population, two different populations were distinguished: a

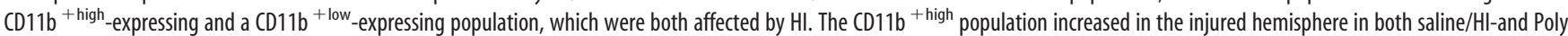
I:C/HI-treated animals. In contrast, the CD11b ${ }^{+ \text {low }}$ population was decreased in the injured hemisphere in both saline/HI- and Poly I:C/HI-treated animals. The CD11b ${ }^{+ \text {high }}$ population in the injured hemisphere was lower in Poly I:C/HI compared with saline/HI animals, whereas the CD11b ${ }^{+ \text {low }}$ population was higher in the injured hemisphere after Poly l:C/HI compared with saline/HI. C, There were no significant changes in M1-like (proinflammatory) $\mathrm{CD} 11 \mathrm{~b}{ }^{+} \mathrm{CD} 86^{+}$cells in the ipsilateral compared with the contralateral hemisphere after either Poly $\mathrm{I}: \mathrm{C} / \mathrm{HI}$ or saline/HI. In contrast, there was a decrease in M2-like (reparative) $\mathrm{CD} 11 \mathrm{~b}^{+} \mathrm{CD}_{206}{ }^{+}$cells in the injured hemisphere in both saline/HI- and Poly I:C/HI-treated animals. In the contralateral hemisphere, the percentage of $\mathrm{CD}_{11 \mathrm{~b}}{ }^{+} \mathrm{CD} 206^{+}$cells was lower in Poly I:C/HI-treated animals compared with saline/HI-treated animals. Data are presented as mean $\pm \mathrm{SEM} ;{ }^{*} p \leq 0.05,{ }^{* *} p \leq 0.01,{ }^{* * *} p \leq 0.001 ; n=8-9$ per group.

we found that $\mathrm{I} \kappa \mathrm{B}$ phosphorylation, an indicator of NF- $\kappa \mathrm{B}$ transcription, was increased. Furthermore, gene expression of both type 1 interferons and other cytokines/chemokines were up regulated in the brain in a TRIF-dependent matter. These findings in WT mice correspond well with previous studies demonstrating an increased expression of IL- 6 , IL- $1 \beta$, TNF- $\alpha$, and MCP- 1 in the adult mouse and guinea pig brain after Poly I:C administration (Cunningham et al., 2007; Konat et al., 2009; Field et al., 2010). Both MCP-1 and IL-1 $\beta$ exacerbate neonatal excitotoxic lesions (Galasso et al., 2000; Favrais et al., 2007), and deletion of the entire TNF gene cluster abolishes LPS-mediated increase in neonatal HI injury (Kendall et al., 2011), suggesting that these cytokines may play a role in inflammatory-induced neonatal brain damage. The direct influence of IL- 6 on the development of brain injury is more controversial. Although studies have consistently demonstrated elevated IL-6 levels in asphyxiated infants (Sävman et al., 1998) and mice overexpressing IL-6 develop severe neurologic syndromes (Campbell et al., 1997), others find that mice deficient in IL-6 develop more severe brain injuries (Penkowa and Hidalgo, 2000). Interestingly, maternal immune activation 
with Poly I:C alters fetal brain development in an IL-6-dependent manner (Smith et al., 2007). However, in our experiments, the findings are correlative, and additional studies, using for example relevant knock-out animals or cytokine stimulation in TRIF KO mice, are needed to determine the specific roles of these inflammatory mediators in TLR-3-induced brain injury.

The inflammatory response was further investigated by flow cytometry analysis after Poly I:C/HI. CD $11 \mathrm{~b}^{+}$microglia were markedly increased in the injured hemisphere after the combination of Poly I:C/HI, which was not seen after saline/HI. Additionally, we discovered that $\mathrm{CD} 11 \mathrm{~b}^{+}$microglia were characterized by two distinct populations of cells: (1) CD11 $\mathrm{b}^{\text {+low }}$-expressing and (2) $\mathrm{CD} 11 \mathrm{~b}^{\text {thigh }}$-expressing cells. The increased population of $\mathrm{CD}_{11 \mathrm{~b}^{+}}{ }^{\text {high }}$-expressing microglia are not likely to represent proinflammatory $\mathrm{CD} 86^{+}$cells as we further demonstrated that M1like $\mathrm{CD} 11 \mathrm{~b}^{+} \mathrm{CD} 86^{+}$cells were not significantly increased in the neonatal brain after saline/HI or Poly I:C/HI. This finding contrasts with reports in $\mathrm{P} 11$ mice having increased $\mathrm{CD} 11 \mathrm{~b}^{+} \mathrm{CD} 86^{+}$ cells by $24 \mathrm{~h}$ after $\mathrm{HI}$ alone (Winerdal et al., 2012). Conversely, we found that a population with anti-inflammatory phenotype, M2like $\mathrm{CD} 11 \mathrm{~b}^{+} \mathrm{CD} 206^{+}$cells, was significantly decreased in the injured hemisphere. These changes were apparent in both saline/HI and Poly I:C/HI brains. The Poly I:C-induced reduction in M2-like CD11b ${ }^{+} \mathrm{CD} 206^{+}$cells was also evident in the noninjured hemisphere, suggesting that Poly I:C by itself, without HI, has an effect on this cell population. In support, we found that Poly I:C-treated sham-operated animals also demonstrate a decrease in $\mathrm{CD}_{11 \mathrm{~b}}{ }^{+} \mathrm{CD} 206^{+}$cells. CD206 is a C-type lectin carbohydrate binding protein expressed by alternatively activated macrophages and associated with recovery and restoration of function (Bhatia et al., 2011). Therefore, our data indicate that poly I:C has a general detrimental effect on "protective" microglia and suggest that, rather than affecting the proinflammatory response, deleterious Poly I:C-mediated effects may instead predominantly downregulate the reparative response. At present, it is unclear whether the $\mathrm{CD} 11 \mathrm{~b}^{+}$cells that we studied represent mainly resident microglia or whether there may also be recruitment of peripheral immune cells into the brain.

In the ischemic brain, Akt signaling pathway is neuroprotective by phosphorylating its substrates and preventing inflammation and apoptosis (Mullonkal and Toledo-Pereyra, 2007). Neonatal HI decreases Akt phosphorylation (Brywe et al., 2005) and in turn increases axonal injury (Xiong et al., 2012). Akt phosphorylation plays an important role in the TRIF signaling pathway and promotes cell survival in response to innate immune stimulation (Park et al., 2006; Joung et al., 2011). In the current neonatal model, Poly I:C transiently decreased Akt phosphorylation and upregulated mRNA for Fas ligand. This later finding is in agreement with the reported Poly I:C-exacerbated neurodegeneration linked to Fas ligand upregulation (Field et al., 2010). Together, our data indicate that dephosphorylation of Akt and release of pro-apoptotic Fas may contribute to the vulnerability of the immature brain against additional injuries such as HI, although additional studies need to confirm this using, for example, specific inhibitors.

To conclude, we demonstrate that activation of the TLR-3/ TRIF pathway before HI markedly increases both white and gray matter injury in a TRIF-dependent manner in neonatal mice. We observed a TRIF-dependent increase in expression of both type I interferons (IFN- $\beta$ ), proinflammatory cytokines (IL-6, IL-1 $\beta$, and TNF- $\alpha$ ) and chemotaxic mediators (IP-10 and MCP-1) after Poly I:C administration, which suggest that both pathways involving NF- $\kappa$ B and IRF- 3 transcription factors are involved in the cerebral response to TLR-3/TRIF stimulation. The inflammatory response to Poly I:C/HI was characterized by a decrease in number of M2-like microglia, suggesting that anti-inflammatory/restorative mechanisms in the brain are diminished after Poly I:C. Poly I:C is a synthetic mimic of dsRNA viral products. Therefore, the Poly I:C-induced increase in vulnerability to $\mathrm{HI}$ observed in the present study may indicate that viral infections in the neonate, acquired prenatally or perinatally, could have great impact on hypoxic-ischemic brain injury in the newborn.

\section{References}

Bhatia S, Fei M, Yarlagadda M, Qi Z, Akira S, Saijo S, Iwakura Y, van Rooijen N, Gibson GA, St Croix CM, Ray A, Ray P (2011) Rapid host defense against Aspergillus fumigatus involves alveolar macrophages with a predominance of alternatively activated phenotype. PLoS One 6:e15943. CrossRef Medline

Brywe KG, Mallard C, Gustavsson M, Hedtjärn M, Leverin AL, Wang X, Blomgren K, Isgaard J, Hagberg H (2005) IGF-I neuroprotection in the immature brain after hypoxia-ischemia, involvement of Akt and GSK3beta? Eur J Neurosci 21:1489-1502. CrossRef Medline

Campbell IL, Stalder AK, Chiang CS, Bellinger R, Heyser CJ, Steffensen S, Masliah E, Powell HC, Gold LH, Henriksen SJ, Siggins GR (1997) Transgenic models to assess the pathogenic actions of cytokines in the central nervous system. Mol Psychiatry 2:125-129. CrossRef Medline

Colton CA (2009) Heterogeneity of microglial activation in the innate immune response in the brain. J Neuroimmune Pharmacol 4:399-418. CrossRef Medline

Craig A, Ling Luo N, Beardsley DJ, Wingate-Pearse N, Walker DW, Hohimer AR, Back SA (2003) Quantitative analysis of perinatal rodent oligodendrocyte lineage progression and its correlation with human. Exp Neurol 181:231-240. CrossRef Medline

Cunningham C, Campion S, Teeling J, Felton L, Perry VH (2007) The sickness behaviour and CNS inflammatory mediator profile induced by systemic challenge of mice with synthetic double-stranded RNA (poly I:C). Brain Behav Immun 21:490-502. CrossRef Medline

Cusson-Hermance N, Khurana S, Lee TH, Fitzgerald KA, Kelliher MA (2005) Rip1 mediates the Trif-dependent toll-like receptor 3- and 4-induced NF-kB activation but does not contribute to interferon regulatory factor 3 activation. J Biol Chem 280:36560-36566. CrossRef Medline

Dammann O, Leviton A (1997) Maternal intrauterine infection, cytokines, and brain damage in the preterm newborn. Pediatr Res 42:1-8. CrossRef Medline

Deleidi M, Hallett PJ, Koprich JB, Chung CY, Isacson O (2010) The Tolllike receptor-3 agonist polyinosinic:polycytidylic acid triggers nigrostriatal dopaminergic degeneration. J Neurosci 30:16091-16101. CrossRef Medline

Eklind S, Mallard C, Leverin AL, Gilland E, Blomgren K, Mattsby-Baltzer I, Hagberg H (2001) Bacterial endotoxin sensitizes the immature brain to hypoxic-ischaemic injury. Eur J Neurosci 13:1101-1106. CrossRef Medline

Eklind S, Mallard C, Arvidsson P, Hagberg H (2005) Lipopolysaccharide induces both a primary and a secondary phase of sensitization in the developing rat brain. Pediatr Res 58:112-116. CrossRef Medline

Famakin BM, Mou Y, Ruetzler CA, Bembry J, Maric D, Hallenbeck JM (2011) Disruption of downstream MyD88 or TRIF Toll-like receptor signaling does not protect against cerebral ischemia. Brain Res 1388:148156. CrossRef Medline

Favrais G, Schwendimann L, Gressens P, Lelièvre V (2007) Cyclooxygenase-2 mediates the sensitizing effects of systemic IL-1-beta on excitotoxic brain lesions in newborn mice. Neurobiol Dis 25:496-505. CrossRef Medline

Field R, Campion S, Warren C, Murray C, Cunningham C (2010) Systemic challenge with the TLR3 agonist poly I:C induces amplified IFNalpha/ beta and IL-1beta responses in the diseased brain and exacerbates chronic neurodegeneration. Brain Behav Immun 24:996-1007. CrossRef Medline

Galasso JM, Liu Y, Szaflarski J, Warren JS, Silverstein FS (2000) Monocyte chemoattractant protein-1 is a mediator of acute excitotoxic injury in neonatal rat brain. Neuroscience 101:737-744. CrossRef Medline

Galic MA, Riazi K, Henderson AK, Tsutsui S, Pittman QJ (2009) Viral-like brain inflammation during development causes increased seizure susceptibility in adult rats. Neurobiol Dis 36:343-351. CrossRef Medline 
Hua F, Wang J, Sayeed I, Ishrat T, Atif F, Stein DG (2009) The TRIFdependent signaling pathway is not required for acute cerebral ischemia/ reperfusion injury in mice. Biochem Biophys Res Commun 390:678-683. CrossRef Medline

Hyakkoku K, Hamanaka J, Tsuruma K, Shimazawa M, Tanaka H, Uematsu S, Akira S, Inagaki N, Nagai H, Hara H (2010) Toll-like receptor 4 (TLR4), but not TLR3 or TLR9, knock-out mice have neuroprotective effects against focal cerebral ischemia. Neuroscience 171:258-267. CrossRef Medline

Joung SM, Park ZY, Rani S, Takeuchi O, Akira S, Lee JY (2011) Akt contributes to activation of the TRIF-dependent signaling pathways of TLRs by interacting with TANK-binding kinase 1. J Immunol 186:499-507. CrossRef Medline

Kendall GS, Hristova M, Horn S, Dafou D, Acosta-Saltos A, Almolda B, Zbarsky V, Rumajogee P, Heuer H, Castellano B, Pfeffer K, Nedospasov SA, Peebles DM, Raivich G (2011) TNF gene cluster deletion abolishes lipopolysaccharide-mediated sensitization of the neonatal brain to hypoxic ischemic insult. Lab Invest 91:328-341. CrossRef Medline

Kim H, Yang E, Lee J, Kim SH, Shin JS, Park JY, Choi SJ, Kim SJ, Choi IH (2008) Double-stranded RNA mediates interferon regulatory factor 3 activation and interleukin- 6 production by engaging Toll-like receptor 3 in human brain astrocytes. Immunology 124:480 - 488. CrossRef Medline

Konat GW, Borysiewicz E, Fil D, James I (2009) Peripheral challenge with double-stranded RNA elicits global up-regulation of cytokine gene expression in the brain. J Neurosci Res 87:1381-1388. CrossRef Medline

Lathia JD, Okun E, Tang SC, Griffioen K, Cheng A, Mughal MR, Laryea G, Selvaraj PK, ffrench-Constant C, Magnus T, Arumugam TV, Mattson MP (2008) Toll-like receptor 3 is a negative regulator of embryonic neural progenitor cell proliferation. J Neurosci 28:13978-13984. CrossRef Medline

Lehnardt S, Massillon L, Follett P, Jensen FE, Ratan R, Rosenberg PA, Volpe JJ, Vartanian T (2003) Activation of innate immunity in the CNS triggers neurodegeneration through a Toll-like receptor 4-dependent pathway. Proc Natl Acad Sci U S A 100:8514-8519. CrossRef Medline

Liu Y, Kimura K, Yanai R, Chikama T, Nishida T (2008) Cytokine, chemokine, and adhesion molecule expression mediated by MAPKs in human corneal fibroblasts exposed to poly(I:C). Invest Ophthalmol Vis Sci 49: 3336-3344. CrossRef Medline

Marsh B, Stevens SL, Packard AE, Gopalan B, Hunter B, Leung PY, Harrington CA, Stenzel-Poore MP (2009) Systemic lipopolysaccharide protects the brain from ischemic injury by reprogramming the response of the brain to stroke: a critical role for IRF3. J Neurosci 29:9839-9849. CrossRef Medline

McWhirter SM, Fitzgerald KA, Rosains J, Rowe DC, Golenbock DT, Maniatis $\mathrm{T}$ (2004) IFN-regulatory factor 3-dependent gene expression is defective in Tbk1-deficient mouse embryonic fibroblasts. Proc Natl Acad Sci U S A 101:233-238. CrossRef Medline

Meyer U, Nyffeler M, Engler A, Urwyler A, Schedlowski M, Knuesel I, Yee BK, Feldon J (2006) The time of prenatal immune challenge determines the specificity of inflammation-mediated brain and behavioral pathology. J Neurosci 26:4752-4762. CrossRef Medline

Meylan E, Burns K, Hofmann K, Blancheteau V, Martinon F, Kelliher M, Tschopp J (2004) RIP1 is an essential mediator of Toll-like receptor 3-induced NF-kappa B activation. Nat Immunol 5:503-507. CrossRef Medline

Mullonkal CJ, Toledo-Pereyra LH (2007) Akt in ischemia and reperfusion. J Invest Surg 20:195-203. CrossRef Medline

Packard AE, Hedges JC, Bahjat FR, Stevens SL, Conlin MJ, Salazar AM, Stenzel-Poore MP (2012) Poly-IC preconditioning protects against ce- rebral and renal ischemia-reperfusion injury. J Cereb Blood Flow Metab 32:242-247. CrossRef Medline

Park D, Lapteva N, Seethammagari M, Slawin KM, Spencer DM (2006) An essential role for Aktl in dendritic cell function and tumor immunotherapy. Nat Biotechnol 24:1581-1590. CrossRef Medline

Penkowa M, Hidalgo J (2000) IL-6 deficiency leads to reduced metallothionein-I+II expression and increased oxidative stress in the brain stem after 6-aminonicotinamide treatment. Exp Neurol 163:72-84. CrossRef Medline

Ratnayake U, Quinn TA, Castillo-Melendez M, Dickinson H, Walker DW (2012) Behaviour and hippocampus-specific changes in spiny mouse neonates after treatment of the mother with the viral-mimetic Poly I:C at mid-pregnancy. Brain Behav Immun 26:1288-1299. CrossRef Medline

Roda JM, Carceller F, Díez-Tejedor E, Avendaño C (1995) Reduction of infarct size by intra-arterial nimodipine administered at reperfusion in a rat model of partially reversible brain focal ischemia. Stroke 26 : 1888-1892. CrossRef Medline

Sasai M, Oshiumi H, Matsumoto M, Inoue N, Fujita F, Nakanishi M, Seya T (2005) Cutting Edge: NF-kappaB-activating kinase-associated protein 1 participates in TLR3/Toll-IL-1 homology domain-containing adapter molecule-1-mediated IFN regulatory factor 3 activation. J Immunol 174: 27-30. Medline

Sato S, Sugiyama M, Yamamoto M, Watanabe Y, Kawai T, Takeda K, Akira S (2003) Toll/IL-1 receptor domain-containing adaptor inducing IFN-beta (TRIF) associates with TNF receptor-associated factor 6 and TANK-binding kinase 1, and activates two distinct transcription factors, NF-kappa B and IFN-regulatory factor-3, in the Toll-like receptor signaling. J Immunol 171: 4304-4310. Medline

Sävman K, Blennow M, Gustafson K, Tarkowski E, Hagberg H (1998) Cytokine response in cerebrospinal fluid after birth asphyxia. Pediatr Res 43:746-751. CrossRef Medline

Smith SE, Li J, Garbett K, Mirnics K, Patterson PH (2007) Maternal immune activation alters fetal brain development through interleukin-6. J Neurosci 27:10695-10702. CrossRef Medline

Svedin P, Hagberg H, Sävman K, Zhu C, Mallard C (2007) Matrix metalloproteinase-9 gene knock-out protects the immature brain after cerebral hypoxia-ischemia. J Neurosci 27:1511-1518. CrossRef Medline

Volpe JJ (2008) Neonatal encephalitis and white matter injury: more than just inflammation? Ann Neurol 64:232-236. CrossRef Medline

Vontell R, Supramaniam V, Thornton C, Wyatt-Ashmead J, Mallard C, Gressens P, Rutherford M, Hagberg H (2013) Toll-like receptor 3 expression in glia and neurons alters in response to white matter injury in preterm infants. Dev Neurosci. Advance online publication. Retrieved June 18, 2013. doi:10.1159/000346158. CrossRef Medline

Vuillermot S, Joodmardi E, Perlmann T, Ögren SO, Feldon J, Meyer U (2012) Prenatal immune activation interacts with genetic Nurrl deficiency in the development of attentional impairments. J Neurosci 32: 436-451. CrossRef Medline

Wang X, Stridh L, Li W, Dean J, Elmgren A, Gan L, Eriksson K, Hagberg H, Mallard C (2009) Lipopolysaccharide sensitizes neonatal hypoxicischemic brain injury in a MyD88-dependent manner. J Immunol 183: 7471-7477. CrossRef Medline

Winerdal M, Winerdal ME, Kinn J, Urmaliya V, Winqvist O, Adén U (2012) Long lasting local and systemic inflammation after cerebral hypoxic ischemia in newborn mice. PLoS One 7:e36422. CrossRef Medline

Xiong T, Tang J, Zhao J, Chen H, Zhao F, Li J, Qu Y, Ferriero D, Mu D (2012) Involvement of the Akt/GSK-3beta/CRMP-2 pathway in axonal injury after hypoxic-ischemic brain damage in neonatal rat. Neuroscience 216 : 123-132. CrossRef Medline 